\title{
The first record of Litargus tetraspilotus (Coleoptera, Mycetophagidae) in Brazil, with biological notes and complementary description of the species
}

\author{
Julianne Milléo ${ }^{1}$, Jonathan P. Castro ${ }^{1}$, Cibele S. Ribeiro-Costa ${ }^{2} \&$ Jana M. T. de Souza ${ }^{3}$
}

1. Laboratório de Bioecologia de Invertebrados, Departamento de Biologia Geral, Universidade Estadual de Ponta Grossa, 84030-900 Ponta Grossa, PR, Brazil. (jmilleo@ hotmail.com; jonathan.penacastro@gmail.com)

2. Laboratório de Sistemática e Bioecologia de Coleoptera, Departamento de Zoologia, Universidade Federal do Paraná, Caixa Postal 19020, 81531-980 Curitiba, PR, Brazil. (stra@ufpr.br)

3. Laboratório de Ecologia Vegetal, Departamento de Botânica, Universidade Federal do Paraná, Caixa Postal 19031, $81531-970$ Curitiba, PR, Brazil. (janamagaly@yahoo.com.br)

\begin{abstract}
Litargus tetraspilotus LeConte, 1856 was collected feeding on Oidium sp. (Fungi, Ascomycota, Erysiphaceae) associated with fruit trees. This is the first time L. tetraspilotus is recorded in Brazil, totaling three species of Mycetophagidae for this country. This study aims to provide a complementary description of this species based on new characters and to present information on its life cycle under laboratory conditions and fluctuation in population in the field. During the period of inventories between July 2004 and August 2006, about every fifteen days, a total of 565 specimens of L. tetraspilotus were collected, with the highest abundance found on citrus plants, with values differing significantly between the two years. The population levels differed between the seasons; spring had the greatest abundance and autumn the least. There was a significant positive correlation of $L$. tetraspilotus abundance with rainfall and relative humidity. Mycetophagidae, as well as other mycophagous families of Brazilian coleopterans, are barely studied, warranting further future studies of their bioecology and systematics.
\end{abstract}

KEYWORDS. Tenebrionoidea, Mycetophagini, fruit trees, mycophagous, population fluctuation.

RESUMO. Primeiro registro de Litargus tetraspilotus (Coleoptera, Mycetophagidae) para o Brasil, com notas biológicas e descrição complementar da espécie. Litargus tetraspilotus LeConte, 1856 foi coletado alimentando-se de Oidium sp. (Fungi, Ascomycota, Erysiphaceae) associado a árvores frutíferas. Litargus tetraspilotus é registrado pela primeira vez no Brasil, totalizando três espécies de Mycetophagidae no país. Esse trabalho teve como objetivos fornecer uma descrição complementar da espécie, com base em novos caracteres e apresentar informações sobre seu ciclo de vida em condições de laboratório e dados de flutuação populacional no campo. Durante o período de inventariamento de julho/2004 a agosto/2006, a cada quinze dias, foram coletados 565 exemplares de $L$. tetraspilotus, sendo os maiores valores de abundância encontrados nas plantas cítricas, com variação significativa entre os dois anos de coleta. Os níveis populacionais diferiram entre as estações, sendo a primavera o período de maior abundância e o outono, o de menor. Houve correlação positiva significativa com a precipitação e a umidade relativa do ar. Mycetophagidae, assim como outras famílias de coleópteros micófagos brasileiros, são muito pouco estudadas, sendo necessário pesquisas futuras sobre sua bioecologia e sistemática.

PALAVRAS-CHAVE. Tenebrionoidea, Mycetophagini, árvores frutíferas, micófago, flutuação populacional.

The family Mycetophagidae (Coleoptera, Tenebrionoidea) comprises around 130 species in 18 genera (LAWRENCE \& LesCHEN, 2010). They are small coleopterans with an oval-shaped, elongated, slightly flattened body and with the dorsal surface punctuated and pubescent. Most of them feed on decomposing fungi and vegetables, and some are found on stored products, indicating bad storage conditions (Воотн et al., 1990; LAWRENCE \& BRITTON, 1991).

During the period between July 2004 and August 2006, a survey of coleopterofauna was performed in fruit trees of the orchard of the Colégio Agrícola Estadual Augusto Ribas, Ponta Grossa, Paraná, Brazil. In analyzing the collections, it was observed that the Mycetophagidae constituted one of the most representative families.

There are records of the Mycetophagidae in state of Paraná, Brazil (Dutra \& MiYAZAKI, 1994; MARINONI \& Dutra, 1997; GANHO \& Marinoni, 2003; 2005; 2006; MARINONI \& GANHO, 2003a); however, the specimens were not identified at the species level. This shows that the Mycetophagidae have not been adequately studied and that taxonomic studies are needed (HINTON, 1945; PARSONS,
1975; LAWRENCE, 1987). According to LesCHEN (1990), the biology of the Tenebrionoidea, in general, is also poorly known.

There are only two Mycetophagidae species previously recorded for Brazil, Typhaea stercorea (Linnaeus, 1758) (Costa Lima, 1953) and Caserus convexus Dajoz, 1969 (DAJoz, 1969). As the material collected in Ponta Grossa was identified as Litargus tetraspilotus LeConte, 1856, we record here a third Mycetophagidae species from Brazil. This species was already recorded for the Americas (HetschKo, 1930; BlaCKWELDER, 1945: Mexico, Guatemala, Nicaragua, Panama and Argentina; Young, 2002, SHockLey \& Cline, 2004: Canada and United States).

In 1900, Casey, who studied the North-American coleopterans, included L. tetraspilotus in a key. He suggested a new subgenus, Tilargus, in which to place L. tetraspilotus, but SHARP (1902) recognized Tilargus as a distinct genus with $L$. tetraspilotus as the type species. The subgenus was not considered by PARSONS (1975), who reviewed the Nearctic Mycetophagidae, and $L$. tetraspilotus was included in a key with other Litargus species. 
The unique information about the life history of $L$. tetraspilotus is that it was found associated with Euvira micmac (Coleoptera, Staphylinidae, Aleocharinae) in galls of red oak in Canada (KLIMASzewski \& MAJKA, 2007).

Due to the scarcity of taxonomic and bioecological information on Neotropical Mycetophagidae, the aims of the present paper are to record one more species, $L$. tetraspilotus, of this family in Brazil and for easier recognition of this species to provide a complementary description with illustrations. Information about its life cycle and ecological aspects of its presence in fruit trees are also included.

\section{MATERIAL AND METHODS}

Collections. Field work was performed at Colégio Agrícola Estadual Augusto Ribas orchard in Ponta Grossa, Paraná, Brazil (2505'42”'S, 5006'17'W; 900 m). The fruit tree species collected using an beating tray were: Citrus nobilis, Citrus sinensis, Citrus limon, Citrus reticulata (Rutaceae), Diospyros kaki (Ebenaceae), Prunus persica and Prunus persica var. nucipersica (Rosaceae). Collections were carried out in the morning, at about every fifteen days, between July 2004 and August 2006.

Identification. In the laboratory, the insects were selected and Mycetophagidae specimens were mounted on entomological pins and labeled. Identification at the family level was done according to Воотн et al. (1990) and at the genus level according to Young (2002) and CASEY (1900), which was later confirmed by Dr. Richard Leschen, Curator of the Department of Coleoptera, New Zealand Arthropod Collection. The specimens were identified at the species level according to PARSONS (1975), using a dichotomous key, and later confirmed by comparisons with holotype images in MCZ TYPE Database (2007). The holotype is deposited at the Museum of Comparative Zoology at Harvard University, Cambridge, USA.

Redescription. Details of the exoskeleton and the male and female genitals were examined. The recognition of the structures and illustrations were carried out at the Laboratório de Sistemática e Bioecologia de Coleoptera, at Universidade Federal do Paraná, using stereomicroscope and a compound microscope, both with a camera lucida attached.

The specimens were boiled in distilled water and neutral soap for nearly four minutes to soften the exoskeleton, and to clarify some parts, 40 volumes of hot hydrogen peroxide were used for a few seconds. The pieces were dissected and arranged on slides with a glycerin drop. To study the genitalia, after their removal from the specimens, the pieces were boiled in $10 \% \mathrm{KOH}$ for two minutes.

Photographs were taken using a stereomicroscope with a digital camera, and images were captured with computer software IM 50 (Image Manager) and combined using the image processing software Auto-Montage Pro (Syncroscopy). Final editing of drawings and photographs was performed in Adobe Photoshop software, version 9.0. Measurements were done using a micrometric ocular in a stereomicroscope.

The terminology used was from Leschen (1990), Lawrence (1987), Ponomarenko (1972) and Leschen \& CARLTON (2004) for female terminalia. The specimens are deposited in the Coleção Entomológica dos Campos Gerais do Paraná, Ponta Grossa, Paraná, Brazil and Coleção de Entomologia Pe. J. S. Moure, Departamento de Zoologia, Universidade Federal do Paraná, Curitiba, Paraná, Brazil.

Life cycle. The adults of L. tetraspilotus were collected during the months between November 2007 and February 2008, while feeding on Oidium sp. (Fungi, Ascomycota, Erysiphaceae) on lemon trees. The bioassays were carried out in the laboratory, under environmental conditions, with an average room temperature of $22.05 \pm 1.44^{\circ} \mathrm{C}$ and relative humidity of $55.68 \pm 10.70{ }^{\circ} \mathrm{C}$. The method used is from WaLLAGE \& Rose (1982) and JАCOB (1988).

The specimens captured in the field were randomly distributed in ten Petri dishes, each containing ten individuals to obtain eggs. Petri dishes were observed daily and the eggs were separated in other Petri dishes with moistened filter paper and a piece of leaf Citrus limon with fungus. After larval eclosion, these were also separated in Petri dishes with moistened filter paper and similar nourishment. Biological parameters (egg laying and incubation period, larval period, pupal period, and adult longevity and sex ratio) were evaluated daily until the death of the individuals. There were 20 repetitions for larvae and adults.

Population fluctuation. The climatic data (minimum temperature and maximum, relative humidity of the air and rainfall) were provided by Instituto Tecnológico SIMEPAR which is $150 \mathrm{~km}$ from the collection area.

Data analyses. The normality of the data was previously tested using the Shapiro-Wilk normality test, and variance homogeneity evaluated using the $\mathrm{F}$ test. Since there was no indication of normality or homogeneity, non-parametric analysis was performed. Monthly abundance data were used to improve the number of repetitions. In order to test the influence of abiotic factors on abundance of $L$. tetraspilotus, KruskalWallis analyses were used. Abundance was utilized as the response variable and year of collection, widely common plants and season were used as factors, using $1 \%$ of significance. To adjust the analysis to the period of collections, which started in July 2004 and finished in August 2006, the seasons were considered as follows: winter, from July to September; spring, from October to December; summer, from January to March; and autumn, from April to June.

To determine the influence of meteorological factors (accumulated rainfall, relative humidity, minimum and maximum temperature) on the population fluctuation of L. tetraspilotus, a Spearman correlation analysis with species abundance on citric plants was performed.

All analyses were performed using R 2.9.2 software. 


\section{RESULTS}

\section{Litargus tetraspilotus LeConte, 1856}

(Figs 1-19)

Complementary description. Dimensions: length: 1.72 mm-2.24 mm; width: $0.92 \mathrm{~mm}-1.20 \mathrm{~mm}(\mathrm{n}=50)$.

Color dark-brown with yellow spots. Body ovoid and elongated in dorsal view, depressed. Dorsal surface shinny, dark-brown with yellow spots, presence of punctuation arranged in series with short and sparse pubescence (Figs 1, 3). Head short, hypognathous and flattened dorsum-ventrally. Eyes prominent, roughly faceted, with a salience facing laterally in the back, from where five long bristles emerge (Fig. 4). Clypeus with apical margin slightly concave, little salient lateral projections with round margins. Labrum apparent, subrectangular, with round apical margin (Fig. 5). Mandibles asymmetrical, with two incisor teeth in which apices are visible in both mandibles and the subapical ends in a tip; left median grinder is more developed than the right one; prostheca developed with short bristles (Fig. 6). Mandibles complete consisting of galea with excavations to receive maxillary palp and separated laciniae; maxillary palpi long with last article being securiform (Fig. 7). Labium with regular mentum, anterior margin of ligula covered by bristles, labial palp short, the last one slender being in the distal portion (Fig. 8). Antenna yellowish, short, subquadrangular scape, pedicel rectangular and twice as long as wide, last antennomeres gradually brown, each antennal club formed by the last three antennomeres: antepenultimate subrectangular and elongated in the apex, penultimate subquadrangular and ultimate subelliptical, dark brown, showing dense and short pubescence in the apex (Fig. 9). Pronotum arcuate, with yellowish lateral corners, larger than the head, narrow and round anteriorly, basal portion as large as the base of the elytra, round lateral margins
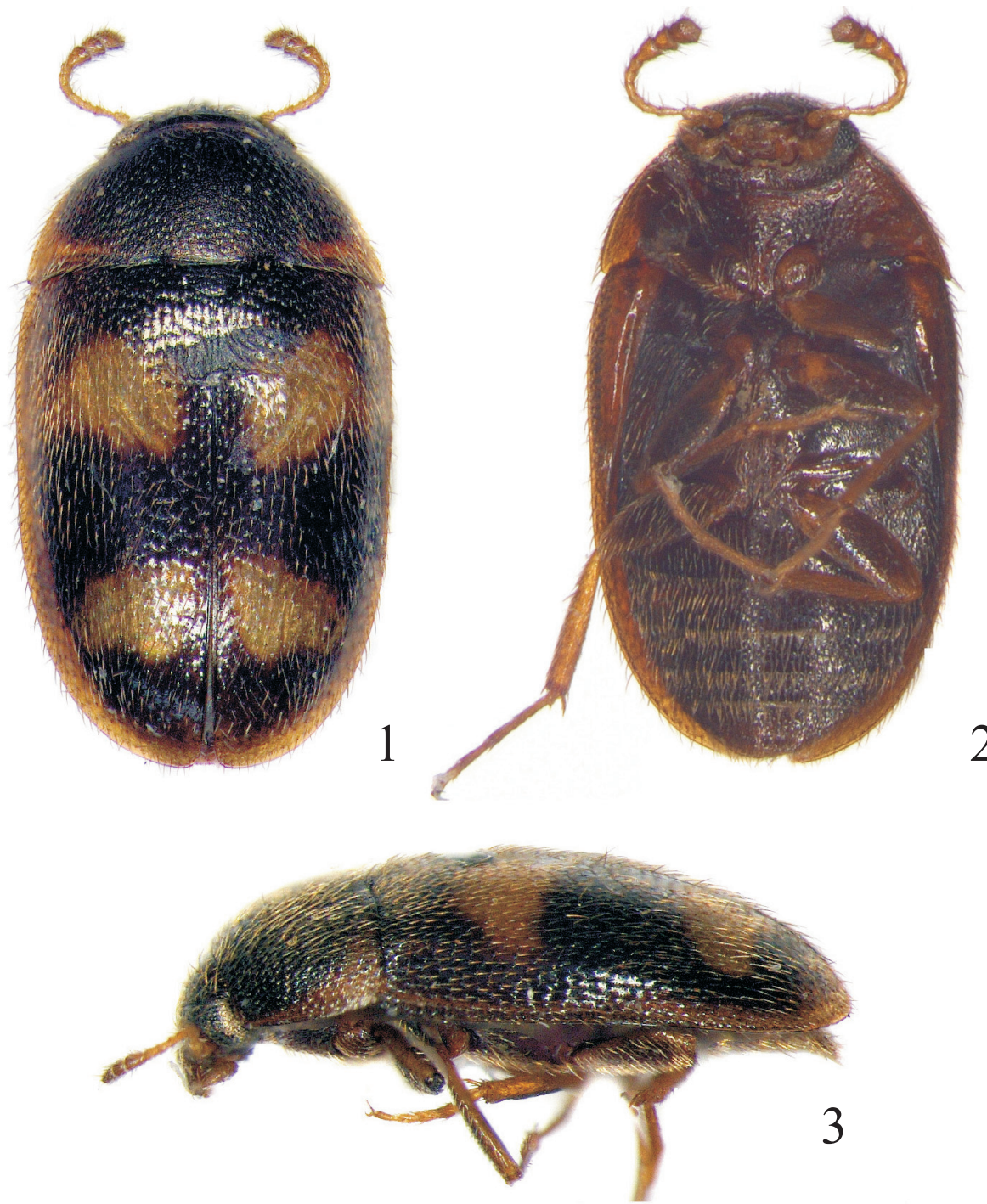

$1 \mathrm{~mm}$

Figures 1-3. Litargus tetraspilotus LeConte, 1856: 1, dorsal view; 2, ventral view; 3, lateral view. 
(Fig. 10). Prosternal process plain (Fig. 11). Elytra entire, the apices rounded; lateral margin usually yellowish; two yellow spots. The first spot is on anterior half of the elytron, oblique, and the second one is on posterior half, subsquare, eventually in "L" form; scutellum of moderate size, with a round apical portion (Figs 1, 3). Epipleura large basally with excavation (Fig. 2). Metendosternite "Y" form, with narrow lateral margins, anterior margin with deep cutting, not visible tendons, long furca arms and facing sideways, lateral and reduced blades (Fig. 12). Wings membranous and well developed, wing venation with costal and subcostal veins reduced by more than onethird of the rib. Ulna vein fused with middle and posterior veins, radial and anal cellules present (Fig. 13). Legs light brown, long and slender; all tibiae with two spurs, projections serrate in the apical region and medially faced; tarsum with slender and elongated tarsomeres (Fig. 14). Male genitalia: lateral stilettos of tegmen with narrow apex; proximal margin ventrally bisinuate, and dorsally projecting over middle lobe, larger at the base. Middle tubular lobe, with half the width of the tegmen proximal margins, with median apical opening, round apex and not proximally wide, with curvature (Fig. 15). Female terminalia: sternite 8 with well-developed spiculum ventrale; base broad, bifurcated with narrow median projection and hyaline. Ovipositor with tergite 9 (paraproct) membranous; anterior half subrectangular and containing a pair of oblique baculi which outline the anterior margin and the separation of tergite 10 , posterior portion membranous and contacting the gonocoxite posteriorly; tergite 10 (proctiger) membranous containing a pair of subtriangular baculi; gonocoxite elongate and cylindrical; gonostylus present, 1/2 length of coxite, with setae scattered along the length and a long sclerotized seta at the apex of each gonostylus (Fig. 16).
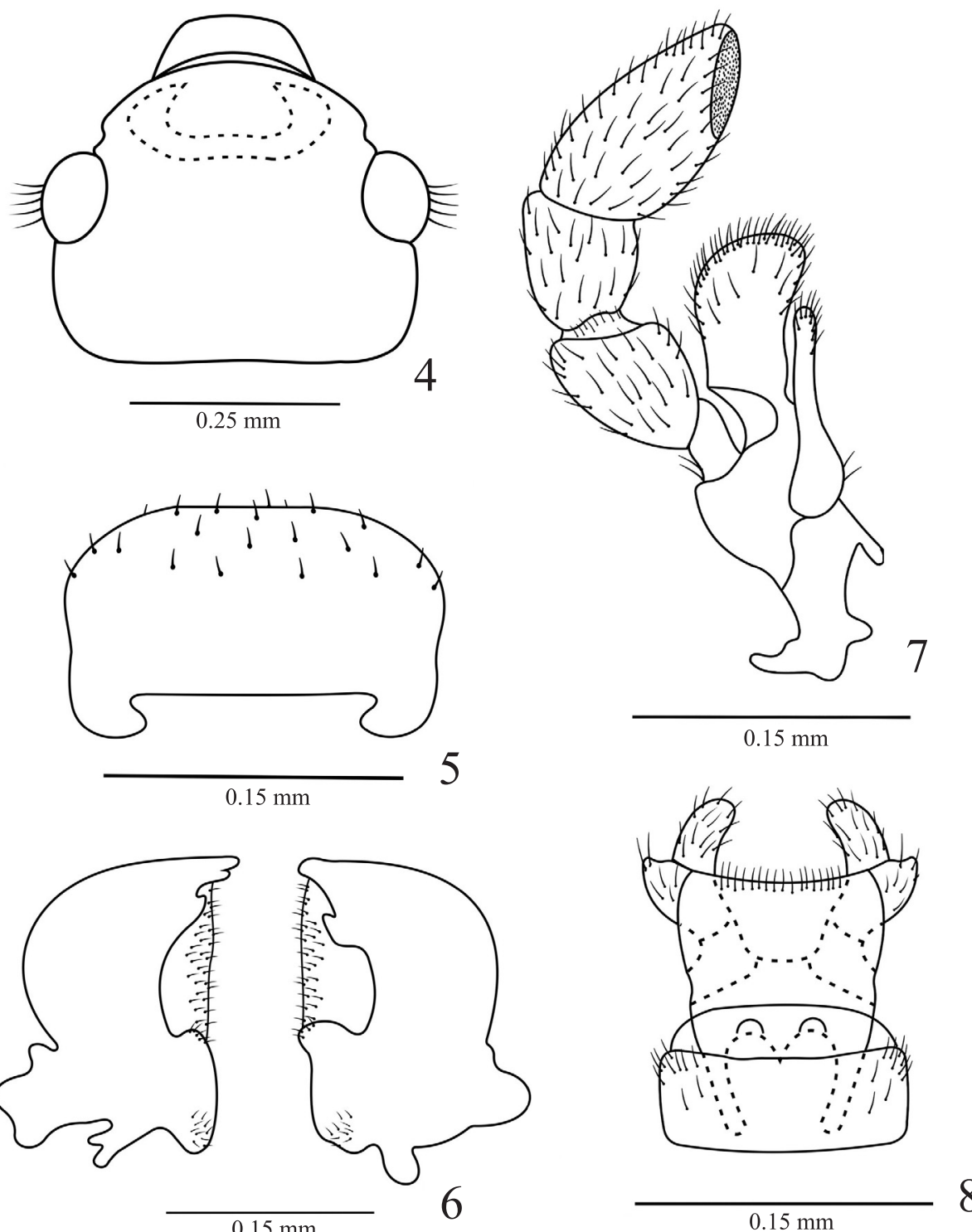
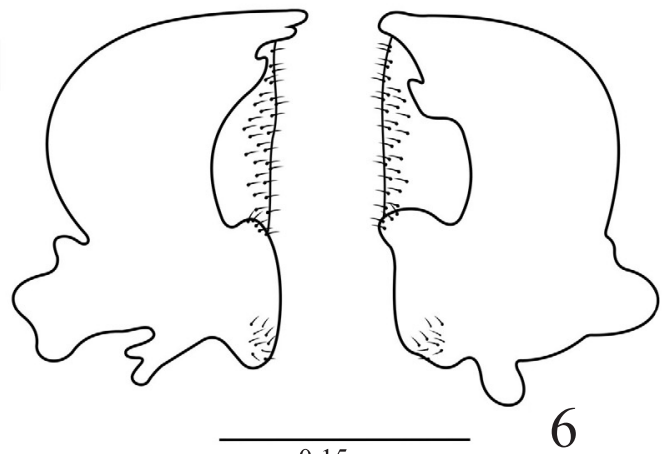

$0.15 \mathrm{~mm}$

$0.15 \mathrm{~mm}$

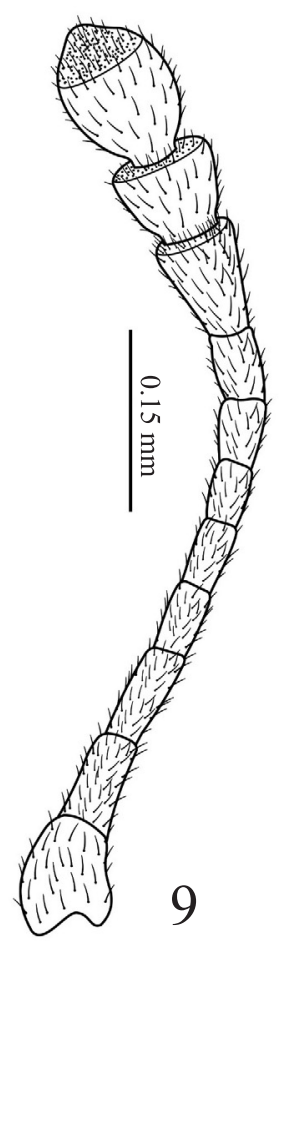

8

Figures 4-9. Litargus tetraspilotus LeConte, 1856: 4, head; 5, labrum; 6, mandibles; 7, maxilla; 8, labium; 9, antenna. 
Life cycle. Egg laying and incubation period. Eggs oval and elongated, white colored (Fig. 17). Usually laid isolated and at places hidden in tree leaves (abaxial region), flower buds or petiole. The average period of incubation, following by the standard deviation, was 3.5 \pm 0.51 days.

Larval period. By counting exuvia in Petri dishes it was possible to determine five larval instars. Larvae are elongate, subcylindrical. Right after eclosion they are whitish, semitransparent and, after a few hours, they become luteous; it is possible to observe bristles distributed uniformly on the body (Fig. 18). During the process of ecdysis, the larvae shelter in protected places and reduce their metabolic activities to perform ecdysis. At 4th and 5th instars, the larvae feed avidly on fungus, until the pre-pupa period, when they remain immobile.

The five instars have the following periods, average with standard deviation: 1 st instar $2.95 \pm 0.69$ days, 2nd instar $3.15 \pm 0.99$ days, 3rd instar $3.4 \pm 0.94$ days, 4th instar $2.55 \pm 0.60$ and 5 th instar $11.85 \pm 1.93$ days. The mean total larval period was $23.9 \pm 2.61$ days, with a range of 17.07 to 30.73 days.

Pupal period. The pupa, exarata type, has white color (Fig. 19). Duration of pupal period showed an average and standard deviation of $5.8 \pm 1.01$ days.
Adults, longevity and sex ratio. Mean longevity of adults was calculated since emergence date of the adult until its death. The average and standard deviation of the lifespan of females was $12.38 \pm 4.48$ days, and males, $13.67 \pm 6.47$ days. Sex ratio was $90^{\circ}: 41$, for a total of 50 dissected insects, which shows the small number of males in the species and explains the difficulty of couple formation in the laboratory.

Information about the duration of the life cycle of L. tetraspilotus is summarized in table I.

Table I. Average duration (days) of the life cycle of Litargus tetraspilotus LeConte, 1856.

\begin{tabular}{lcc}
\hline & Period & $\begin{array}{c}\text { Average duration (days) } \\
\pm \text { standard deviation }\end{array}$ \\
\hline Egg & & $3.5 \pm 0.51$ \\
Larva & $1 \mathrm{st}$ & $2.95 \pm 0.69$ \\
& $2 \mathrm{nd}$ & $3.15 \pm 0.99$ \\
& $3 \mathrm{rd}$ & $3.4 \pm 0.94$ \\
& $4 \mathrm{th}$ & $2.55 \pm 0.60$ \\
Pupa & $5 \mathrm{th}$ & $11.85 \pm 1.93$ \\
Adult & & $5.8 \pm 1.01$ \\
& Male & $13.67 \pm 6.47$ \\
Total & Female & $12.38 \pm 4.48$ \\
\hline
\end{tabular}
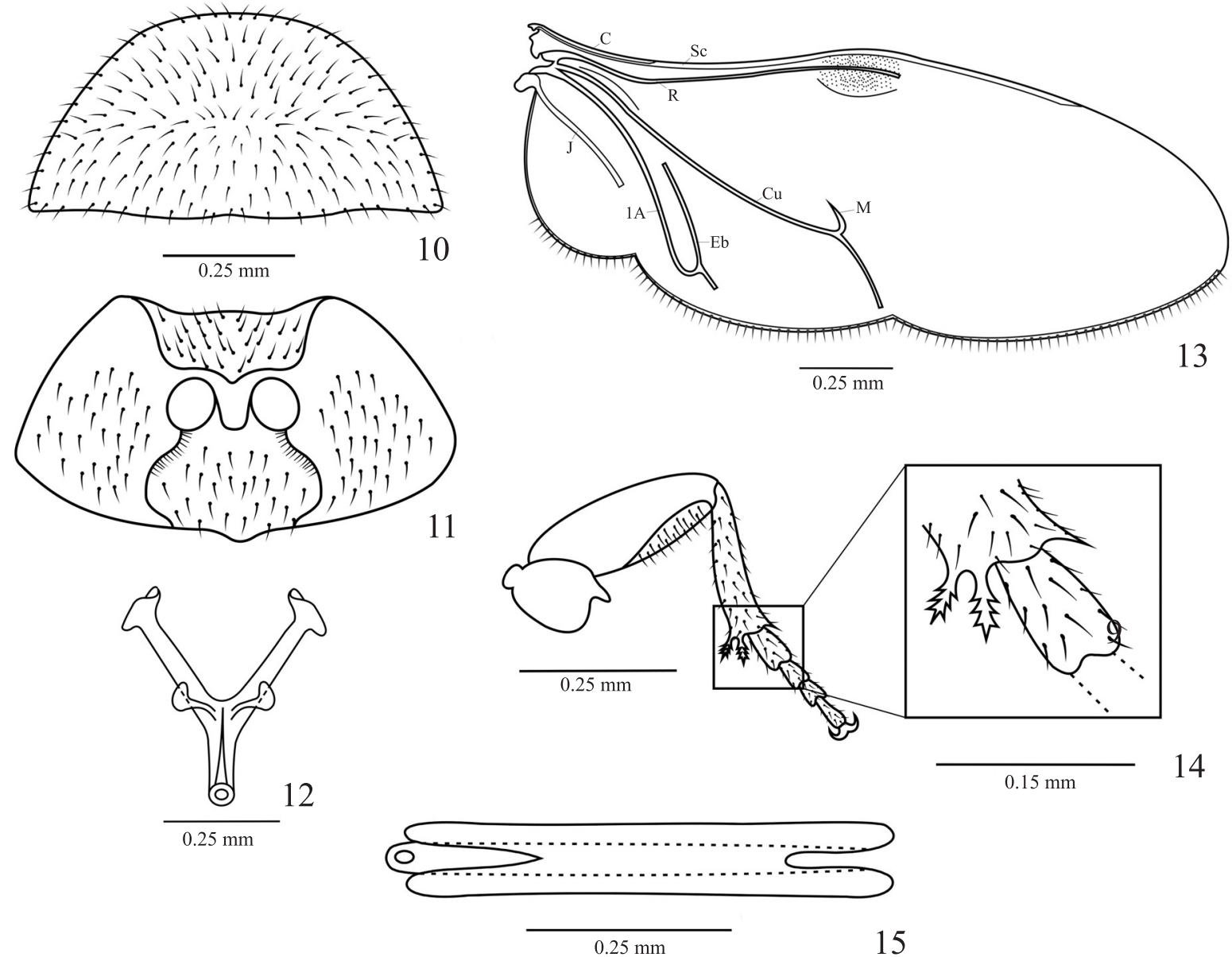

Figures 10-15. Litargus tetraspilotus LeConte, 1856: 10, pronotum, dorsal view; 11, pronotum, ventral view; 12, metendosternite; 13, wing; 14, front leg; 15, tegmen. 


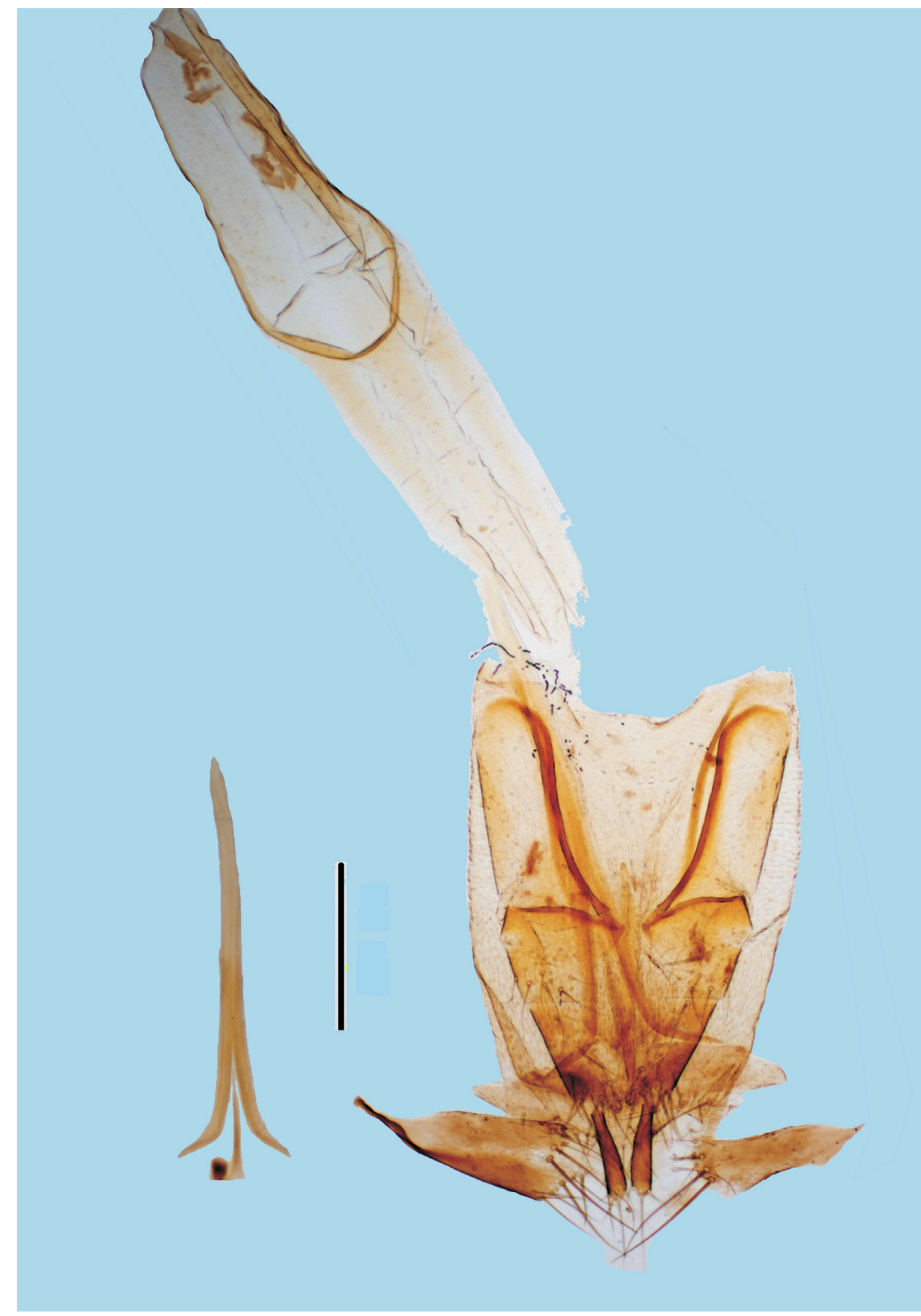

Figure 16. Litargus tetraspilotus LeConte, 1856: 16, female terminalia (detail of spiculum ventrale). Scale line: $20 \mu \mathrm{m}$.

Population fluctuation. During the inventory period, a total of 565 specimens of L. tetraspilotus were collected feeding on Oidium sp. on the following fruit trees: lemon $(34 \%)$, orange $(22 \%)$, mandarin orange $(13 \%)$, peach $(10 \%)$, tangerine $(8 \%)$, nectarine $(5 \%)$, Japanese persimmon (5\%) and pear (2\%) (Tab. II).

Litargus tetraspilotus was not distributed equally among the fruit trees sampled (Kruskal-Wallis: $\mathrm{H}=33.8967$; d.f. $=7 ; \mathrm{p}<0.01)$. The highest abundance values of $L$. tetraspilotus were found in citrus plants, specially lemon and orange (Tab. II). The only exception was tangerine trees, which had similar abundance compared to deciduous plants (mandarin orange, nectarine, pear and peach trees).
The species had distinct population levels during seasons (Kruskal-Wallis: $\mathrm{H}=13.0744$; d.f. $=3$; $\mathrm{p}<0.01$ ). Spring was the period of highest abundance and autumn was the period of lowest (Tab. II).

There was a significant positive correlation of the abundance of L. tetraspilotus with the accumulated rainfall and relative humidity of the air (Tab. III; Figs 20, 21).

Litargus tetraspilotus abundance varied significantly between the two years of collection (Kruskal-Wallis: $\mathrm{H}=11.4755$; d.f. $=1$; $\mathrm{p}<0.01$ ), decreasing considerably in the second annual cycle (Tab. II). 

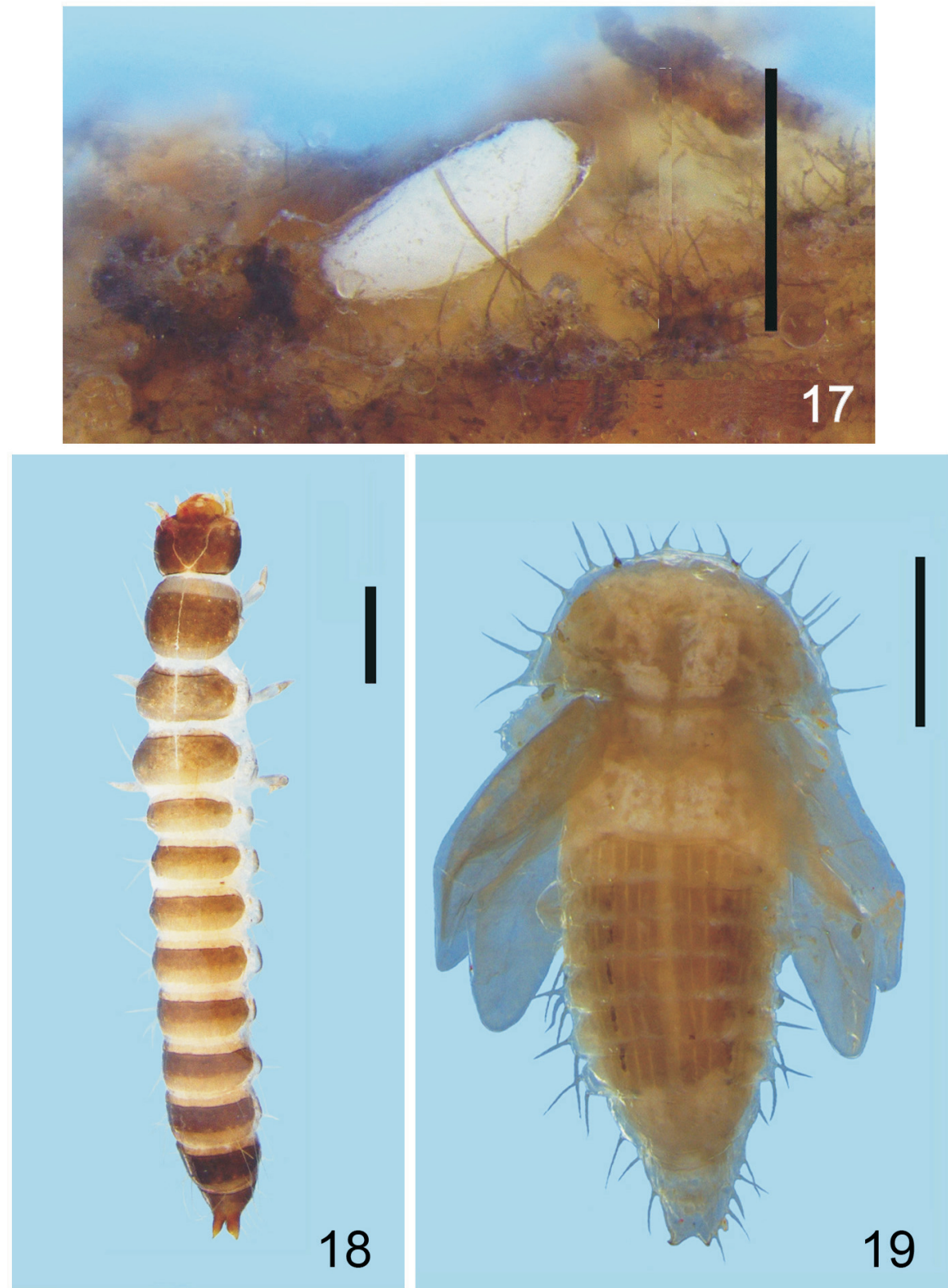

Figures 17-19. Litargus tetraspilotus LeConte, 1856: 17, egg; 18, larva, 5th instar; 19, pupa. Scale lines: $0.5 \mathrm{~mm}$.

Table II. Litargus tetraspilotus LeConte, 1856 sampled during the different seasons on different trees in Ponta Grossa, Paraná, Brazil, between July 2004 and August 2006.

\begin{tabular}{|c|c|c|c|c|c|c|c|c|c|c|c|c|c|}
\hline & \multicolumn{4}{|c|}{$\begin{array}{c}\text { First year } \\
2004 / 2005\end{array}$} & \multicolumn{4}{|c|}{$\begin{array}{l}\text { Second year } \\
2005 / 2006\end{array}$} & \multicolumn{4}{|c|}{$\begin{array}{c}\text { Two years } \\
2004 / 2006\end{array}$} & \multirow[t]{2}{*}{ Total } \\
\hline & Win & $\mathrm{Spr}$ & Sum & Aut & Win & $\mathrm{Spr}$ & Sum & Aut & Win & $\mathrm{Spr}$ & Sum & Aut & \\
\hline \multicolumn{14}{|l|}{ Citrics } \\
\hline Lemon & 61 & 44 & 8 & 23 & 13 & 14 & 31 & 0 & 74 & 58 & 39 & 23 & 194 \\
\hline Mandarin orange & 22 & 35 & 2 & 6 & 7 & 4 & 0 & 0 & 29 & 39 & 2 & 6 & 76 \\
\hline Orange & 44 & 28 & 3 & 13 & 27 & 6 & 1 & 3 & 71 & 34 & 4 & 16 & 125 \\
\hline Tangerine & 8 & 20 & 0 & 2 & 2 & 11 & 0 & 0 & 10 & 31 & 0 & 2 & 43 \\
\hline \multicolumn{14}{|l|}{ Deciduous } \\
\hline Japanese persimmon & 0 & 12 & 1 & 0 & 0 & 0 & 13 & 2 & 0 & 12 & 14 & 2 & 28 \\
\hline Peach & 1 & 29 & 14 & 0 & 0 & 9 & 4 & 0 & 1 & 38 & 18 & 0 & 57 \\
\hline Pear & 0 & 4 & 3 & 1 & 0 & 0 & 2 & 2 & 0 & 4 & 5 & 3 & 12 \\
\hline Nectarine & 9 & 9 & 5 & 1 & 0 & 0 & 5 & 1 & 9 & 9 & 10 & 2 & 30 \\
\hline Total & 145 & 181 & 36 & 46 & 49 & 44 & 56 & 8 & 194 & 225 & 92 & 54 & 565 \\
\hline
\end{tabular}


Table III. Correlation values (Spearman) between Mycetophagidae abundance and meteorological factors, sampling with beating tray in different trees in Ponta Grossa, Paraná, Brazil, between July 2004 and August 2006; * significant correlation $(\mathrm{p}<0.05)$.

\begin{tabular}{lc}
\hline & Mycetophagidae abundance \\
\hline Accumulated rainfall & $0.55^{*}$ \\
Relative humidity of the air & $0.41^{*}$ \\
Minimum temperature & 0.15 \\
Average temperature & -0.20 \\
Maximum temperature & 0.02 \\
\hline
\end{tabular}

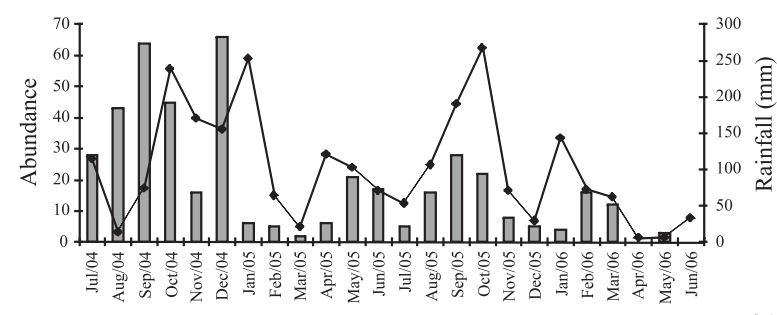

21

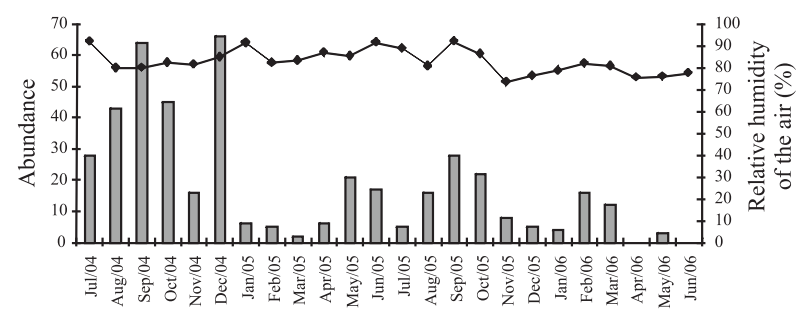

Figures 20, 21. Population fluctuation of Litargus tetraspilotus LeConte, 1856 in citrus plants and meteorological factors from July 2004 to June 2006, in Ponta Grossa, PR, Brazil: 20, monthly values of accumulated rainfall $(\mathrm{mm}) ; 21$, monthly values of relative humidity of the air (\%).

\section{DISCUSSION}

Taxonomy. The descriptions of the other Brazilian Mycetophagidae species are very poor in details, making it difficult to perform comparisons with $L$. tetraspilotus. The most conspicuous difference between $L$. tetraspilotus and the other two Brazilian species is the general color of the body being dark, i.e., brown with four yellowish spots on the elytra, and punctuation arranged in series. Typhaea stercorea has a light brown dorsal surface (Costa Lima, 1953) and Caserus convexus, has a brown dorsal surface (DAJOZ, 1969), with both species having no spots.

Life cycle. Considering the egg laying and incubation period, in comparison to other species of Mycetophagidae, for which there is information about the life cycle, the incubation period of L. tetraspilotus is the shortest one. Triphyllus minor (Lea, 1895) has an average incubation period of 7.5 days (WALLAGE \& Rose, 1982), while for Typhaea stercorea the average is 4.9 days, at similar temperature and humidity conditions ( $\mathrm{J}_{\mathrm{ACOB}}$, 1988).

The duration of the larval period of L. tetraspilotus is close to that of Triphyllus minor which has a mean duration of 28.4 days (Wallage \& Rose, 1982). The authors observed that the last instar larvae also consume large amounts of fungus, and when this resource becomes sparse, the larvae show cannibalistic tendencies. The developmental period of Typhaea stercorea larvae showed a longer average duration compared to the others, i.e., about 83.5 days ( $\left.\mathrm{J}_{\mathrm{ACOB}}, 1988\right)$.

Pupal period. The mean duration of the pupal period of L. tetraspilotus was similar to that of the other species: Triphyllus minor with 7.5 days and Typhaea stercorea with 5.0 days (Wallage \& Rose, 1982; J JCOB, 1988).

The data for longevity and sex ratio in adults were not determined for T. minor, as for T. stercorea.

Population fluctuation. The highest abundance values of L. tetraspilotus were found on citrus plants, especially lemon and orange, which can be related to the fact that these plants have persistent leaves favoring the presence of the fungi and consequently of $L$. tetraspilotus for longer periods. The lemon tree stood out among the citrus plants because, besides being able to sustain the highest number of individuals, it was the only fruit tree in which the presence of insects could be considered continuous since the species was captured in around $60 \%$ of the samples. This finding indicates that there is possibly a higher concentration of Oidium sp. on this plant.

About population levels during seasons, the spring is the period of highest abundance like in other insect groups, such as the Muscidae (COSTACURTA et al., 2003), Cerambycidae (Marinoni \& Ganho, 2003b), Syrphidae (MARINONi et al., 2006) and Chrysomelidae (LiNZMEIER \& Ribeiro-Costa, 2008).

The significant positive correlation of the abundance of $L$. tetraspilotus with the relative humidity of the air was not found in the two other studies examining the seasonality of coleopterans in the municipality of Ponta Grossa. Both investigations showed a negative tendency between relative humidity of the air and the number of individuals collected (MARINONI \& GANHO, 2003b, for a Cerambycidae species; LinZMEIER \& RIBEIROCosta, 2008, for a chrysomelid community). It was possibly due to the different feeding habits of the groups: herbivorous (Cerambycidae, Chrysomelidae) and fungivorous (Mycetophagidae). Fungi need humidity to proliferate and they possibly reach higher levels of abundance during the periods when they find these conditions. In addition, the sampling method used in the studies cited above was Malaise, where insects are captured in flight. High levels of humidity make their locomotion more difficult, thereby reducing their capture, which does not occur with active capture.

The abundance varied significantly between the two years of collection, which demonstrates the species has a marked temporal oscillation. The population reduction from the first to the second year of sampling can be associated with higher mean values of relative humidity of the air and accumulated rainfall in the first annual cycle (85\% and $1402.3 \mathrm{~mm}$, respectively) compared to the second $(80.6 \%$ and $1042.7 \mathrm{~mm})$, or may be due to as yet unknown factors.

Acknowledgments. The authors thank the following people: Professor Jail Bueno, technical director of Colégio Agrícola Estadual Augusto Ribas, for allowing entrance to the cultivated areas and sampling; Dr. Richard Leschen (Curator of the Department of Coleoptera, New Zealand Arthropod Collection) 
for the identification of the genus; Dr. Maristella Dalla Pria, from Departamento de Fitotecnia e Fitossanidade, UEPG, for the identification of the fungus; Osmar Stringari, manager of Instituto Tecnológico SIMEPAR, for making climatic data available ; project "Taxon line - Rede Paranaense de Coleções Biológicas", of the Departamento de Zoologia of UFPR for the capture of the images; MSc. Geovan Henrique Corrêa, for assistance with the drawings; academic Thatyla Luana Beck Farago, for the organization of the fluctuation data; academic Shyguek Nagazak Alves Miayamoto for final artwork in the drawings; Dr. A. Leyva helped with English editing of the manuscript

\section{REFERENCES}

Blackwelder, R. E. 1945. Checklist of the coleopterous insects of Mexico, Central America, the West Indies, and South America. Bulletin of the United States National Museum 185(3):343-550

Воотн, R. G.; Cox, M. L. \& Madge, R. B. 1990. IIE Guides to insects of importance to man: 3. Coleoptera. London, International Institute of Entomology/The Natural History Museum. 384p

Casey, T. L. 1900. Review of the American Corylophidae, Cryptophagidae, Tritomidae and Dermestidae with other studies. Journal of the New York Entomological Society 8:51-172.

Costa Lima, A. 1953. Família Tritomidae. In: Costa Lima, A. Insetos do Brasil: Coleópteros. Rio de Janeiro, Escola Nacional de Agronomia. Tomo 8, Cap. XXIX. p.266-268.

Costacurta, N. C.; Marinoni, R. C. \& Carvalho, C. J. B. 2003. Fauna de Muscidae (Diptera) em três localidades do Estado do Paraná, Brasil, capturada por armadilha Malaise. Revista Brasileira de Entomologia 47(3):389-397.

Dajoz, R. 1969. Contribution a L'Étude des Coléoptères Mycetophagidae. II - Un Coléoptère Mycetophagidae nouveau du Brésil: Caserus convexus. Bulletin de la Société Entomologique de France 74:79-81.

Dutra, R. R. C. \& Miyazaki, R. D. 1994. Famílias de Coleoptera capturadas em oito localidades do Estado do Paraná, Brasil. Brazilian Archives of Biology and Technology 37(4):889-894

Ganho, N. G. \& Marinoni, R. C. 2003. Fauna de Coleoptera no Parque Estadual de Vila Velha, Ponta Grossa, Paraná, Brasil. Abundância e riqueza das famílias capturadas através de armadilhas Malaise. Revista Brasileira de Zoologia 20(4):727-736

2005. A diversidade inventarial de Coleoptera (Insecta) em uma paisagem antropizada do Bioma Araucária. Revista Brasileira de Entomologia 49(4):535-543.

2006. A variabilidade espacial das famílias de Coleoptera (Insecta) entre fragmentos de Floresta Ombrófila Mista Montana (Bioma Araucária) e plantação de Pinus elliottii Engelmann, no Parque Ecológico Vivat Floresta, Tijucas do Sul, Paraná, Brasil. Revista Brasileira de Zoologia 23(4):1159-1167.

Hetscho, A. 1930. Phalacridae, Mycetophagidae, Tretothoracidae, Jacobsoniidae, Cavicoxumidae, Gnostidae. Coleopterorum Catalogus 15(108): 1-47.

Hinton, H. E. 1945. A monograph of the beetles associated with stored products, Mycetophagidae. London, British Museum (Natural History). v.1, p.168-176.

$\mathrm{J}_{\mathrm{ACOB}}$, T. A. 1988 The effect of temperature and humidity on the developmental period and mortality of Typhaea stercored (L.) (Coleoptera: Mycetophagidae). Journal of Stored Products Research 24(4):221-224.

Klimaszewski, J. \& Majka, C. G. 2007. Euvira micmac, a new species (Coleoptera: Staphylinidae:Aleocharinae), and first record of the genus in Canada. The Canadian Entomologist 139(2): 147-153

Lawrence, J. F. 1987. Notes on the classification of some Australian Tenebrionoidea (Coleoptera). Journal of the Australian Entomological Society 26:361-362.

Lawrence, J. F. \& Britton, E. B. 1991. Coleoptera (Beetles). In: Naumann, I. ed. The Insects of Australia. A textbook for students and research workers. Melbourne, Melbourne University (CSIRO). v.2, p.543-683.

Lawrence, J. F. \& Leschen, R. A. B. 2010. Chapter 11.1 Mycetophagidae Leach, 1815. In: Leschen, R. A. B.; Beutel, R. G. \& Lawrence, J. F. eds. Handbook of Zoology, Coleoptera Volume 2: morphology and systematics (Elateroidea, Bostrichformia, Cucujiformia partim). Berlin, Walter de Gruyter. p.491-496.

Leschen, R. A. B. 1990. Tenebrionoid-Basidiomycete relationships with comments on feeding ecology and the evolution of fungal monophagy (Coleoptera/Hymenomycetes). University of Kansas Science Bulletin 54:165-177.

Leschen, R. A. B. \& Carlton, C. E. 2004. A new tribe, genus and species of Nitidulidae bettle (Coleoptera: Nitidulidae: Nitidulinae) from Bolivia. The Coleopterists Bulletin 58(3):443-451.

Linzmeier, A. M. \& Ribeiro-Costa, C. S. 2008. Seasonality an temporal structuration of Alticini community (Coleoptera, Chrysomelidae, Galerucinae) in the Araucaria Forest of Paraná, Brazil. Revista Brasileira de Entomologia 52(2):289-295.

Marinoni, R. C. \& Dutra, R. R. C. 1997. Famílias de Coleoptera capturadas com armadilha Malaise em oito localidades do Estado do Paraná, Brasil. Diversidades alfa e beta. Revista Brasileira de Zoologia 14(3):751-770.

Marinoni, R. C. \& Ganho, N. G. 2003a. Fauna de Coleoptera no Parque Estadual de Vila Velha, Ponta Grossa, Paraná, Brasil. Abundância e riqueza das famílias capturadas através de armadilhas de solo. Revista Brasileira de Zoologia 20(4):737-744.

2003b. Sazonalidade de Nyssodrysina lignaria (Bates) (Coleoptera, Cerambycidae, Lamiinae) no Estado do Paraná, Brasil. Revista Brasileira de Zoologia 20(1):141-152.

Marinoni, L.; Marinoni, R. C.; Jorge, C. M. \& Bonnatto, S. R. 2006. Espécies mais abundantes de Syrphidae (Diptera) em dois anos de coletas com armadilhas Malaise no Estado do Paraná, Brasil. Revista Brasileira de Zoologia 23(4):1071-1077.

MCZ Type Database. 2007. Database of insect primary types in the collection of the Museum of Comparative Zoology at Harvard University. Available at: <http:// insects.oeb.harvard.edu/MCZ/index.htm> Access on: 11.07.2009

Parsons, C. T. 1975. Revision of the Nearctic Mycetophagidae (Coleoptera). The Coleopterists Bulletin 29(2):93-108.

Ponomarenko, A. G. 1972. The nomenclature of wing venation in beetles (Coleoptera). Entomological Review 51(4):454-458.

SharP, D. 1902. Lathridiidae, Mycetophagidae, Dermestidae. In: Godman, F. \& Salvin, O. eds. Biologia Centrali-Americana - Insecta, Coleoptera. London, Dulau and Co. v.2., p.625-688.

Shockley, F. W. \& Cline, A. R. 2004. A contribution to the inventory of Coleoptera of Missouri: new records from Benton County. Journal of the Kansas Entomological Society 77(3):280-284.

Wallage, G. N. \& Rose, H. A. 1982. Some Aspects of the biology of Triphyllus minor (Lea) (Coleoptera: Mycetophagidae). Australian Journal of Entomology 21:111,112.

Young, D. K. 2002. Mycetophagidae Leach 1815. In: ARNETT JR., R. H.; Thomas, M. C.; Skelley, P. E. \& Frank, J. H. eds American Beetles: Polyphaga: Scarabaeoidea through Curculionoidea. Boca Raton, CRC. v.2. p.399,400. 